\title{
Did you just say what I think you said? Talking about genes, identity and information
}

\author{
Adam Henschke
}

Received: 15 March 2010 /Accepted: 13 August 2010/Published online: 26 August 2010

C The Author(s) 2010. This article is published with open access at Springerlink.com

\begin{abstract}
Genetic information is becoming increasingly used in modern life, extending beyond medicine to familial history, forensics and more. Following this expansion of use, the effect of genetic information on people's identity and ultimately people's quality of life is being explored in a host of different disciplines. While a multidisciplinary approach is commendable and necessary, there is the potential for the multidisciplinarity to produce conceptual misconnection. That is, while experts in one field may understand their use of a term like 'gene', 'identity' or 'information' for experts in another field, the same term may link to a distinctly different concept. These conceptual misconnections not only increase inefficiency in complex organisational practices, but can also have important ethical, legal and social consequences. This paper comes at the problem of conceptual misconnection by clarifying different uses of the terms 'gene', 'identity' and 'information'. I start by looking at three different conceptions of the gene; the Instrumental, the Nominal and the Postgenomic Molecular. Secondly, a taxonomy of four different concepts of identity is presented; Numeric, Character, Group and Essentialised, and their use is clarified. A general concept of Information is introduced, and finally three distinct kinds of information are described. I then introduce Concept Creep as an ethical problem that arises from conceptual misconnections. The primary goal of this paper is to reduce the potential for conceptual misconnection when discussing genetic identity and genetic information. This is complimented by three secondary goals - 1) to clarify what a conceptual misconnection is, 2) to explain why clarity of use is particularly important to discussions of genes, identity and information and 3 ) to show how concept creep between different uses of genetic identity and genetic information can have important ethical outcomes.
\end{abstract}

Keywords Gene $\cdot$ Identity Information · Ethics · Conceptual misconnection · Concept creep

\footnotetext{
A. Henschke $(\bowtie)$

Charles Sturt University, Centre for Applied Philosophy and Public Ethics (CAPPE),

L.P.O. Box 8260, ANU, Acton 0200 ACT, Australia

e-mail: adam.henschke@anu.edu.au
} 


\section{Conceptual misconnections}

Imagine you are asked to resolve an argument between Frank and his friend, Carter. Frank had asked Carter to buy him a book on Darwin. Frank gave Carter money, and Carter dutifully returned with a book, a biography of Charles Darwin. 'Fool,' Frank cried, 'I wanted a book on the Australian town, Darwin. Not that bearded Ape!' Now the two stand in front of you demanding that you say who is right. Wisely, you reply that in one sense they are both right; Darwin does refer to Charles Darwin, the Australian town Darwin, and a few more. Yet in another sense they are both wrong; When Frank asked Carter to buy the book, he should have made it clear which Darwin he was referring too. However, Carter could have sought clarification about which Darwin Frank meant.

While this confusion, what I call a conceptual misconnection, is a common event in interpersonal communication, conceptual misconnections can cause significant problems in areas of interdisciplinary communications. Essentially, while one discipline has a common understanding of what they mean by a given word, another discipline has a different, though equally correct meaning of the same word. If different disciplines use the same words for different concepts, but don't realise that other disciplines mean different concepts, inefficiencies, confusion or worse can arise. To display this, throughout this paper, I will use two examples that use genetic information to describe identity. One example is considered in the context of forensic DNA profiles, and the other in the context of antisocial activity and behavioural genetics. They have been chosen to show how different conceptions arise, and in the final section, to illustrate the problem of concept creep.

This paper has three main sections; what, how and why. Firstly, I wish to introduce the idea of conceptual misconnection in practice. Doing this will answer the question of 'what does conceptual misconnection mean?' Secondly, to answer 'how does a conceptual misconnection occur?', I will describe the particular mechanisms of conceptual misconnections, as they relate to genes, identity and information. Finally, I will demonstrate the importance of recognising the potential hazards of conceptual misconnections, by showing 'why ought we care about conceptual misconnection.'

Prior to discussing concepts and misconnections, three more points need to be made. Firstly, there is no single 'right' concept for a given word. Often there are sound historical and practical reasons for the same word to track to different concepts (Griffiths and Stotz 2006). The correct approach is not to prescribe that one concept is the right one, rather, it is to show that different concepts exist. Secondly, on the nomenclature that I have used, some disciplines may find my terms are not the most common ones used in their particular area. Finally, the taxonomy offered here is not the only way to carve up the concepts. Christine Hauskeller, for example, offers a different taxonomic approach to similar problems discussed in this paper (Hauskeller 2004).

\section{What does conceptual misconnection mean?}

The example of Frank and Carter was intended to be a paradigmatic example of a conceptual misconnection. That is, the concept of Darwin that Frank meant was a 
different concept of Darwin that Carter understood Frank to mean. Words can have different meanings that track to different concepts. Problems arise, however, when people communicate and unknowingly use the same word to track to different concepts: this is a conceptual misconnection. Consider a phone call put through to the wrong department: the problem is not that the caller has been disconnected, rather, the problem is that the caller has been put through to the wrong department, the caller has been misconnected. Likewise, Frank meant the Australian town Darwin, and Carter misconnected to the person Charles Darwin, Carter has connected to a concept that Frank did not have in mind.

The issue of conceptual misconnections can be more than simple instances of people talking past each other. Consider the phrase 'genetic information used to determine criminal identity.' If talked about in a context of forensic DNA databases, this phrase seems reasonably unproblematic: an individual's genetic fingerprint has been used to identify them at the scene of a particular crime. Yet if used in a different context, talking about genes determining antisocial behaviour, the phrase becomes ethically charged: a particular group of people with a particular genetic profile are expected to be naturally inclined towards antisocial activity. Depending on the context, the phrase 'genetic information used to determine criminal identity' can have very different meanings.

If these multiple meanings are a problem, then perhaps we can resolve this by working out what the meaning is. But 'meaning' itself is not a simple concept. While there are numerous ways of understanding 'meaning', (Putnam 1975; Sellars 1975), this paper will use an account of 'meaning' that follows the one developed by Herbert Grice (Grice 1957). Very simply, Grice's account holds that meaning is a speaker intentionally producing a change or response in an audience. In the cases I am interested in, the desired change is a change in the knowledge state of the audience. Simply, that the speaker intends that the audience has new knowledge as the result of their speech act.

Even avoiding extensional meaning (Putnam 1975), and limiting discussion to 'meaning as concept', speaker intention alone does not fully capture meaning. We also have to consider the meaning that the audience has. If anything like the 'language of thought' hypothesis (Fodor 1975) is correct, then concepts are necessary for producing thoughts, and if people begin with different concepts, they will have different thoughts. Thus, if Carter has a different concept of Darwin in his mind than Frank's, his meaning of Frank's request will be different to what Frank intended. And here we have what I mean by 'conceptual misconnection': Frank intends for his speech act to produce in Carter the concept of the town Darwin, while Carter receives the message as the man Darwin. Frank's intention has been unsuccessful, his message misunderstood.

So I have now answered the question 'what do I mean by conceptual misconnection'-speaker and audience track different concepts to the same word. Why would such an incident arise? One part of the explanation is context: in one context Darwin is typically understood to refer to the town, while in another context it commonly refers to the man. No doubt the confusion about Darwin would be less likely within a group of Australian geographers or a group of evolutionary biologists. The risk of a conceptual misconnection seems far less when the speakers belong to a common group. But context only explains part of the problem. To 
explain particular conceptual misconnections, we need to look to a second part of the explanation which looks at the content of different concepts.

\section{How does a conceptual misconnection occur? Exploring concepts of gene, identity and information}

Three concepts of the gene

I will begin with what may seem the most straightforward of the three words to be discussed; 'gene' and introduce three concepts that it tracks to, the Instrumental Gene, the Nominal Gene and the Postgenomic Molecular Gene. As Evelyn Fox Keller argues "the ways in which we talk about scientific objects are not simply determined by empirical evidence but rather actively influence the kind of evidence we seek (and hence are more likely to find)" (Keller 1995). Even something like the 'gene', which seems like a clear concept, has multiple meanings. Following Paul E. Griffiths and Karola Stotz's taxonomy, I describe the Instrumental and Nominal gene concepts. ${ }^{1}$ Further to this, Griffiths and Stotz propose that there is, at least, a third concept of the gene- - the Postgenomic Molecular Gene (Griffiths and Stotz 2006).

The instrumental gene

Griffiths and Stotz describe the Instrumental Gene as a factor "in a model of transmission of a heritable phenotype, or in a population genetic model of a changing population" (Griffiths and Stotz 2006). Very simply described, the Instrumental concept of the gene is "[d]efined with respect to phenotype but indeterminate with respect to DNA sequence" (Moss 2004). The Instrumental Gene contrasts specifically with the Nominal concept of the gene, which will be discussed in the next section. The important points to note about the Instrumental Gene are that it was initially in use in the time prior to the understanding of the physical structure of DNA, and that it is typically used in reference to heritability studies and population genetics.

Historically, the Instrumental concept of the gene developed prior to a clear understanding of the molecular process of DNA-directed protein expression. The contexts in which genes were studied were plant and animal breeding, populations and embryology. The methods used to understand the inheritance of traits were probabilistic explanations of phenotypic occurrences in populations and through time.

The Instrumental concept of the gene tracks "to a sense of the gene defined by its relationship to a phenotype" and is related to "an ability to predict, within certain contextual limits, the likelihood of some phenotypic trait" (Moss 2004). A paradigmatic example of the Instrumental Gene would be the gay gene, 'discovered'

\footnotetext{
${ }^{1}$ Note that there are other terms used to track to these two concepts: Raphael Falk's Instrumental and Material Genes (Falk 1986), and Lenny Moss' Gene-P and Gene-D (Moss 2004). As Griffith's and Stotz's Postgenomic Molecular Gene concept plays an important role in this paper, I have elected to use the terminology they use.
} 
in the early 1990s (Conrad and Markens 2001). In 1993, a paper published in Science claimed: "DNA linkage analysis...revealed a correlation between homosexual orientation and the inheritance of polymorphic markers on the X chromosome... Xq28" (Hamer et al. 1993). Most relevant for the current discussion is the example itself-DNA analysis reveals a given trait, male homosexual orientation, which is then described as a gene. Note that the role that DNA plays in the Instrumental Gene is to link the trait to DNA by reference to probable position based on phenotype. In the gay gene example, the trait of complex social behaviour.

Recognition of different gene concepts becomes relevant as the different concepts inform how we deal with genetic information. For example, Short Tandem Repeats (STRs) form the informational basis of genetic profiles used in forensic DNA databases like CODIS (U.S. Government 2010) and the NDNAD (U.K. Government 2006). Particular STRs are chosen as they are highly conserved variants in noncoding sections of DNA (Chakraborty et al. 1999). Given that there are ethical concerns about using genetic information in a forensic context, ${ }^{2}$ forensic DNA databases use STRs that do not code for protein expression so they limit the amount of information that can be derived from the STR profile about the person. The DNA database then creates informational profiles about people that are considered to ethically equivalent to fingerprints (Williams and Johnson 2006). Forensic STR profiles are introduced as a "morally acceptable'3 use of genetic information and identity, given the social importance of crime reduction.

\section{The nominal gene}

Following the elucidation of the physical organisation of DNA, genetic sciences went molecular. The early twentieth century saw the concept of a material gene composed of nucleic acids gaining credence (Falk 1986) in genetic research. However, it was not until the "physico-chemical understanding of the organization of these nucleic acids" (Falk 1986) offered in Watson and Cricks"4 seminal paper, Molecular Structure Of Nucleic Acids: A Structure For Deoxyribose Nucleic Acid (Watson and Crick 1953), that the science of molecular genetics really crystallised. As the scope of molecular genetics broadened and deepened, a concept of the gene emerged that was fundamentally different to that of the Instrumental Gene: what Griffiths and Stotz call the Nominal Gene. Recalling that the Instrumental Gene tracks to phenotypes and inheritance, the Nominal Gene concept is explicitly molecular. That is, the Nominal Gene concept refers to DNA sequences involved directly in protein synthesis. Central to this concept is linear correspondence

\footnotetext{
${ }^{2}$ As many different ethical issues arise, I cannot list them here. However, coverage of some of these particular ethical issues, can be found in the June 2006 special edition of The Journal Of Law, Medicine And Ethics.

${ }^{3}$ I put morally acceptable here in scare quotes to call attention to the shortcut I am taking. There are a number of ethical problems raised with respect forensic DNA profiles and their use, that cannot be discussed in this paper.

${ }^{4}$ This mention of Watson and Crick in isolation is not meant to propose that it was them alone who elucidated the physical organisation of DNA. The Nobel Prize and Watson's book The Double Helix among other places recognise the necessary roles of Maurice Wilkins and Rosalind Franklin in discovery of the double helix of DNA.
} 
between molecules, in this case, between DNA and proteins (Griffiths and Stotz 2006).

Protein synthesis displays direct correspondence between the order of DNA base pairs and specific proteins. AAA will direct the amino acid lysine to be added to a protein molecule. By a simple extension of linear correspondence, the Nominal Gene is the DNA sequence directly responsible for ordering the amino acid sequence in a protein. A paradigmatic example would be genetically engineered plants, with inserted bacterial genes to protect them against insects, pesticides etc.

An example by Griffiths and Stotz shows how 'gene' can be understood as Instrumental or Nominal:

Consider, for example, a report of the localization of a "gene for" a psychiatric disorder to some chromosomal region. Clearly one way to interpret such a report is as a prediction that a sequence straightforwardly encoding a protein or a functional RNA - a nominal gene-will be found at that locus. But it is equally legitimate to interpret the report as evidence that something about that locus makes a heritable difference to the disease phenotype (Griffiths and Stotz 2006).

'MAOA' is one example of a relevant Nominal Gene. The MAOA gene, also known as 'the warrior gene' the first gained attention in 1993 (Mann 1994) when it was linked with "impulsive aggression, arson, attempted rape, and exhibitionism" (Brunner et al. 1993). MAOA refers to a Nominal Gene, a known genetic sequence linked with corresponding protein, that puts "[m]ale carriers of low MAOA activity alleles...at risk for becoming a gang member and, once a gang member...at risk for using weapons in a fight" (Beaver et al. 2010). Beyond illustrating the concept of a Nominal Gene, I introduce the 'warrior gene' as an ethically charged ${ }^{5}$ use of genetic information, particularly when the information is used in conjunction with identity, as we will see later.

The postgenomic molecular gene

There is (at least) a third distinct concept that Griffiths and Stotz contend should also to be considered as a gene. They term this concept the 'Postgenomic Molecular Gene'. In their 'deflationary' account of genes as "things you can do with your genome" they state that "an adequate general conception of the molecular gene must acknowledge that genes are defined by the way DNA sequences are used in particular cellular and broader contexts, and not merely by their structure" (Griffiths and Stotz 2006). Similar to the Nominal Gene, the Postgenomic Molecular account is framed by molecular research, but steps beyond the correspondence thesis of the nominal gene, "making the gene a flexible, context-dependent entity" (Griffiths and Stotz 2006). Hence it is molecular, and not an Instrumental Gene, while being postgenomic in that the context in which the molecular gene expresses itself is essential to understanding the gene. "The factors that interactively regulate genomic expression are far from mere background conditions or supportive environment;

\footnotetext{
${ }^{5}$ By ethically charged I mean something that clearly raises ethical concerns. The opposite term that I use is ethically inert, for something that seems to pose no ethical relevance to a given situation.
} 
rather they are on par with genetic information since they co-specify the linear sequence of the gene product together with the target DNA sequence" (Griffiths and Stotz 2006 Emphasis Original).

The importance of these postgenomic factors on eventual organism function cannot be understated. "One study has revealed a large number of transcriptional events, $60 \%$ of which involve novel transcriptional units outside the annotated genic regions, and the rest of which involve newly discovered exons or exon isoforms of known genes" (Griffiths and Stotz 2006). As Raphael Falk said over two decades ago, "[t]oday the gene is not just the material unit, or the instrumental unit of inheritance, but rather $a$ unit, $a$ segment that corresponds to $a$ unit-function, as defined by the individual experimentalist's needs" (Falk 1986).

The Postgenomic Molecular Gene Concept challenges the idea of STRs discussed in the Instrumental Gene Concept. STRs were chosen as forensic tools particularly because they are not functional i.e. not Nominal Genes. Yet, the STRs could be Instrumental Genes and they could be Postgenomic Molecular Genes. Note also that the allelic variants of the MAOA gene may be Nominal Genes or Postgenomic Molecular Genes. The example cited (Beaver et al. 2010) talks about "functional polymorphism in the promoter region of the [MAOA] gene." So, depending on where one sits, this paper could be talking about either the Nominal Gene or the Postgenomic Molecular Gene.

What a recognition of the three different gene concepts tells us is that we must clear what we mean talking about 'genes'. Simply labelling a section of DNA as 'non-coding' does not mean the given sections are not genes. STR profiles present an example of a transdisciplinary conceptual miscommunication. The STRs were deemed ethically inert due to the fact that they were not conceptualised as genes. But, the STRs are only 'non-genes' in when considering one conception of the gene. In the translation from molecular biology to other disciplines, we lose the ethical inertness of the forensic STRs. A person's STR profile becomes more than a genetic fingerprint, now ethically different to the established forensic methodological tool of dusting for fingerprints. Likewise, reference to 'warrior genes' overlooks the contextual role described by Postgenomic Molecular Genes: to talk of MAOA and behaviour, we must talk of environmental context.

\section{Four concepts of identity}

As with 'gene', 'identity' is a word that is used frequently in both common and technical talk. But, as with 'gene', identity tracks to a number of different concepts. Identity can be a deceptively simple word to use, as its meaning seems obvious. My identity is me, your identity is you, his identity is him and so forth. But there are at least four different concepts which identity can track to. The four concepts and their chief concerns are: Numeric Identity, concerned with a person's persistence through time; Character Identity, the qualitative personality of an individual; Group Identity, socio-political communities; and Essentialised Identity, reduction of a person to a specific identifier.

Two points are necessary to make about what follows in this section. Firstly, I will not be seeking to argue what the content of a given concept should be-Numeric Identity, in particular, has a long history of people arguing about what it is (Perry 
$2008 \mathrm{~b}$ ). The purpose here is to give enough of an idea of each concept of identity to make it reasonably distinct from the other concepts. Secondly, while distinct, the four concepts inform each other. That is, what is said about one concept can have an important relationship to another.

\section{Numeric identity}

The concept of Numeric Identity is concerned with what is needed for a thing to be the same as itself. When thinking about persistence, we find that the two fundamental concepts that guide discussions about numeric identity are sameness and time. That is, if time passes, how do we know that $X$ is still $X$ ? Applying such a concept to people, we can ask what makes me now the same person I was yesterday?

Before expanding this out further, I must point out that using the name Numeric Identity for this concept may be considered unorthodox. I will be discussing mostly the persistence of people through time, and typically in philosophy this area is called Personal Identity. That is, what is needed for a person to persist through time? Numeric Identity is normally used in relation to things, inanimate objects. The reason for choosing Numeric Identity, rather than Personal Identity is twofold. Firstly, the term Personal Identity can immediately bring to mind the concept of a personality, a person's psychological or Character Identity (discussed next). By using Numeric Identity instead, I hope to make the concept itself distinct from Character Identity. Secondly, Personal Identity, while used in philosophy to relate to persistence through time, is often used in the fields like social sciences and psychology to relate to a person's psychological or character identity. I need to stress, however, that Numeric Identity, as I describe it, can be equivalent to Personal Identity, when working in the context of philosophy.

We probably all agree that the water in a river may change, but the river remains the same (Perry 1978). Most accounts hold that sameness through time does not have to mean exactly the same; but if we allow for change, then how do we know that something or someone is the same as they were? Thinking about people, the person who I was when I was young is vastly different in size, shape, knowledge, outlook etc. as I am now. And if I live to be eighty, I will be vastly different to who I am now. But despite these changes, most of us would say that I am the same person I was when I was ten years old, and up until I die (and possibly beyond) I will still be the same person. That is, my identity persists through time, despite the obvious fact that I change. How do we explain this?

John Locke offered memory as a way of explaining a single Numeric Identity for people through time. ${ }^{6}$ I know that I am the same person I was when I was ten years old because I remember that I was that person. Likewise, when I am eighty, I will remember who I am now and so can say that I have had the same identity through time, despite whatever changes have occurred. But there are problems with the memory criterion-false memories (Levy 2007), circular reasoning (Perry 2008a). Locke's view was developed into that of 'psychological connectedness' whereby the

\footnotetext{
${ }^{6}$ Note that Locke's Memory Criterion of Identity is often given as Locke's Memory Criterion of Personal Identity. As I mentioned before, the term Personal Identity is typically used in philosophical discussions of this sort.
} 
criterion for numeric identity is that a person's psychological states connect through time. Psychological continuity requires overlapping chains of direct psychological relations (Parfit 1971, 1987). Put simply, the person I am today is very similar to the person I was yesterday. The person I was yesterday is very similar to the person I was two days before, and so on. So though I may not be similar now to the boy I was when I was ten years old, there is a continuity of states that links the person I was then to the person I am now.

But there are others who deny the psychological criterion of identity, and instead propose that the proper criterion for numeric identity is the body (DeGrazia 2005). Eric Olson describes this as the 'somatic approach' (Olson 2007). The reason for this, so the somatic theory goes, is that the correct criterion for identity is not psychological connectedness but persistence of the body itself. "When someone lapses into a persistent vegetative state...friends and relatives rarely conclude that their loved one no longer exists, even when they believe that there is no mental continuity of any sort between the human vegetable and the person" (Olson 2007). Other modern examples of the somatic approach include The Self And The Future (Williams 1970) and Personal Identity And Dead People (Mackie 1999).

Numeric Identity is concerned with issues of sameness through time. It asks how do I know if I am the same person today as I was yesterday? Genes and Numeric Identity have a relation. Forensic STRs, as mentioned, are conceived as non-coding DNA sequences that are used to identify an individual, equivalent to a fingerprint. The STR profile matches to the concept of Numeric Identity. STR profiles are used in the process of determining whether a person is the same person as a potential criminal, i.e. sameness through time.

In this way, 'genetic identity' can be cashed out as a genetic profile of a forensic STRs. And, as mentioned before, this genetic identity is often assumed to be ethically inert, the same as a fingerprint. The reasoning follows that P1) if a genetic identity is the same as a fingerprint, and P2) we allow fingerprints to be used and kept on record to fight crime, then $\mathrm{C}$ ) we ought to allow genetic identities to be part of important social institutions like fighting crime. However, as introduced in the Gene section, this line of reasoning may be flawed, as the first premise P1 relies on one concept of the gene.

\section{Character identity}

Different to Numeric Identity concept of Identity is the Character Identity concept. ${ }^{7}$ The concept of Character Identity is concerned with characterising a person. It is the concept that tracks to a question of the sort 'what am I like?' Imagine you are setting up a blind date between your workmate Alexandria and your friend Ramon. While you will, no doubt, need to give Alexandria something to identify Ramon, like a photo or a visual description, you will probably also describe the sort of person Ramon is. Chances are that this description would be a set a of qualitative traits: he's a good person, funny, shy and a little introverted. In essence, you are giving a character reference for Ramon.

\footnotetext{
${ }^{7}$ Note that Character Identity might also be called psychological identity, or even personal identity, depending on the discipline.
} 
Confusion can arise between Numeric Identity and Character Identity for a number of reasons. Both concepts take into account a person existing through time, and if one takes the psychological criterion of identity to be the proper location for identity persistence, then memory is an important part. Likewise, Character Identity is heavily reliant upon memory. Neil Levy writes: "Our identities...are diachronic entities: I am the sum of my plans and policies; I work towards a goal and I understand myself in terms of my background - where I'm coming from, as we say, is where I come from...Memory links my past to my future self, and makes me the person I am" (Levy 2007).

Note the important difference between Numeric Identity and Character Identity: Numeric Identity seeks to determine if I am the same person as I was yesterday, while Character Identity seeks to describe the sort of person I am. My character is liable to changes through time, and sometimes these changes can be profound. For example, consider we meet an old friend, formerly a lesbian anarchist vegan who is now straight, works as a corporate manager and eats meat regularly. We are likely to agree when she says she is a different person, but we don't take that as meaning that her Numeric Identity has changed. Rather, we acknowledge that the traits, qualities and characteristics of her identity that we knew are now different. In short, though the person has persisted, her character has changed. Her identity (Numeric) is the same, while her identity (Character) is different.

Now let us return to the MAOA example, considered in terms of genes and identity. As described by Nelly Alia-Klein et al., "studies provide evidence linking the low MAOA genotype and violent behavior but only through interaction with severe environmental stressors during childhood" (Alia-Klein et al. 2008). Beaver et al extend this to explore correlations between low MAOA genotypes with gang membership and weapon use (Beaver et al. 2010). This Nominal Gene, the low-MAOA variant, is correlated with character traits like aggression, gang membership and particular behaviours like weapon use. The point here to highlight is that genetic information is being explicitly and directly linked to an individual's personality, with their Character Identity. Compounding this are issues of Group Identity, in particular, race.

\section{Group identity}

So far I discussed identity as it relates to persistence and to character, but have said little about the context or content of a person's identity. While it is true that our identities, in the character sense are psychological, it seems trivially true. That is, if we don't know where this identity comes from, we can end up with a very thin account of identity. The third concept of identity, Group Identity, is concerned with the content and context of a person's identity. That is, the social environment that goes into forming a person's identity.

If identity is seeking 'the sources of the self' as Charles Taylor describes it (Taylor 1989), then the Enlightenment ideal of the self as separate from society is recognised, at best, as a fiction. We need to acknowledge the social embeddedness of our identities - our relations with others are essential to the development of our identities. "[P] ersons are fundamentally social beings who develop the competency for autonomy through social interaction with other persons" (Friedman 2000). Our Character Identity is heavily influenced by the social groups that we identify with, 
and the groups that others identify us with. "One is a self only among other selves. A self can never be described without reference to those who surround it" (Taylor 1989). At the same time, these social groups are in part determined by the individuals that they are composed of; and by those who compose the groups. "I am part of their story, as they are part of mine. The narrative of any one life is part of an interlocking set of narratives" (MacIntyre 2008).

Group identity becomes particularly important in discussion of identity politics. As Taylor says in his seminal essay The Politics Of Recognition;

[A] person or group of people can suffer real damage, real distortion, if the people or society around them mirror back to them a confining or demeaning or contemptible picture of themselves. Nonrecognition or misrecognition can inflict harm, can be a form of oppression, imprisoning someone in a false, distorted, and reduced mode of being (Taylor 1994).

Recognition of Group Identity entails that when I describe a friend as a lesbian anarchist vegan, I am not simply listing a set of attributes associated with the person, I am acknowledging the vital role of society in formatting her identity and ascribing a set of values to that person. When I say 'she is female', I am not only saying that her identity (Numeric) is (and possibly always was) female, nor am I saying that her identity (Character) is as a female, but I am also saying that the identity (Group) that I identify her with is that of the female type, whatever that might be.

Genetic information is a wonderful tool and can produce a great deal of new information. Tissue samples left at crime scenes can be genetically analysed in ways that assist in investigating crimes and identifying possible culprits. In fact, an unknown person's genome can be analysed to predict familial relatedness (Greely et al. 2006), facial morphology and race (Ossorio 2006), even the last name of unknown males (Jobling 2001). DNA evidence left at crime scenes has been used in the U.K. and U.S. to identify individuals based on family members who are already in forensic DNA databases (Williams and Johnson 2004), or to narrow investigations to particular racial minorities (Ossorio 2006). In some cases, these processes have led to convictions of previously unknown culprits (Ossorio 2006; Williams and Johnson 2004).

The link here is that the Group Identity collapses into genetic information and is then used as a shortcut of proxy for family groups, racial groups, surnames etc. So, while a Group Identity like 'race' which is now understood to be a complex social construction (Haslanger 2000, 2005; Smedley and Smedley 2005) genetic information has been and is being used to target criminal investigations to racial groups (Ossorio 2006). I will argue later these ethical concerns arise in part through the process of conceptual misconnection leading to concept creep.

\section{Essentialised identity}

Perhaps one of the core concerns about Group Identity occurs when we reduce a person to a narrow set of group identity attributes. 'Lesbian anarchist vegan', for example, reduces my friend simply to this set of attributes. To describe someone as simply 'a lesbian', 'an anarchist', 'a vegan' etc. can be ethically problematic for two reasons. First, given the historical treatments of minorities, a reductionist description 
can recall and reinforce discrimination. There is a second problem with describing a person in this way: they cease to be a person and become simply that trait. Their human essence has been reduced to a single 'fact', a stereotype (Straub 2002). In this fourth concept of identity, Essentialised Identity, the person identified becomes merely that identifier. Their rich and complex Character Identity is reduced to a basic identifier, an essence.

This process can de-personalise an individual, or group of people, in a number of significant ways. Firstly, it denies that they are any more than the given attributes. Secondly it allows the person to be considered no longer as a person but as an $X$, where that $X$ is the given attribute-lesbian, anarchist, vegan etc. Thirdly, such a process can deny a person the right to wilfully create their own identity in the way Frankfurt and Mackenzie describe it (Frankfurt 1971; Mackenzie 2008). Essentialising a person's identity can reduce their capacity to conceive of the values that are incorporated into their character identity (Mackenzie 2000).

In addition to the three concepts of the gene, we now have four concepts of identity. Add the two words together and now the potential for conceptual misconnection increases. Saying that 'identity is in genes', can now mean a number of different things. One person may mean that Numeric Identity is given by Instrumental Gene profiles, such as that confirmed by forensic DNA profiling. For another person, they may mean that behaviour, Character Identity, is determined by the expression of Nominal Genes. A third person might disagree, saying that identity isn't in the genes, meaning that Postgenomic Molecular Genes vary differential Nominal Gene expression in response to environmental conditions such that Instrumental Genes, while confirming Numeric Identity, have very little to say about Character Identity. Though Instrumental Genes may be useful in describing linkages of Group Identities, they should not collapse individuals into Essentialised Identity.

When we have simplified genetic explanations for complex behaviours, like the MAOA 'warrior gene', and genetic shortcuts for complex social relationships and phenomena like family and race, we reduce complex individuals to simple single genetic identities. The explicit links noted by Alia-Klein et al. between MAOA and severe childhood stresses (Alia-Klein et al. 2008) get lost in the translation from scientific reporting to public communication. Suddenly a rich and complex individual and their particularly relevant personal history becomes reduced to 'warrior gene'. One of the real risks in conceptual misconnections is that complexity of causal relationships get lost across different disciplines, and what was once probabilistic correlations between nominal genes and individual behaviour becomes simple genetic determinism, an Essentialised Identity.

One of the significant controversies about the 'warrior gene' is that was reported to be significantly common in Maoris (Wensley and King 2008). Individual Character Identity gets reduced to Group Identity and Group Identity gets essentialised such that Maoris are genetically predetermined to be violent gang members likely to use weapons. Underlying this determinism and reduction are two important concepts. Firstly, the conceptual misconnections between different concepts of identity. Secondly, that labelling something 'genetic information' implies an objective, scientifically based foundation which grants objective status to the Essentialised Identity claims. 
To contrast the effect that different concepts have in different contexts, consider these two quotes: "There is no doubt that the DNA Expansion Programme has been a tremendous example of how forensic science can be used to support the detection of crime, enormous progress has been made and impressive results have been obtained. Where DNA evidence is available there is a far greater chance of identifying a suspect" (Mennell and Shaw 2006) and "[ $\mathrm{t}]$ he scientists were described as hiding behind a veneer of supposedly "objective" western science, using it to perpetuate "racist and oppressive discourses"" (Wensley and King 2008). Both are talking about the relation between genes and identity in a context of criminal justice, yet one is full of praise, while the other is strongly critical. The difference is that one group takes identity to be Numeric, while another sees it as Essentialised. This is not surprising, considering that the first example is talking about STR profiles and identification, while the second example is talking about MAOA and racism. It is important to highlight that each speaker has reason for their positions. The point here is to show how different disciplines are using different concepts of genes and identity, leading to different valuations on outcomes.

\section{Three kinds of information}

Different to the two other main sections of discussion in this paper, Gene and Identity, this section on information will use a slightly different approach. In this section, a very broad concept of information will be described and then three different kinds of information will be introduced; Source Information, Message Information and Receiver Information. The general concept of information can be described as (at least) three different kinds. As with the previous sections, gene and identity, these three different information kinds need to be made distinct from each other, conceptually. The relevance of the different kinds of information is the role that information plays in informing people's concepts.

\section{General concept of information}

A common way of conceptualising information is in the sequence of data, information and knowledge (Zins 2007). One begins with data, as one gets more data, one has information, and information produces knowledge. Luciano Floridi's account (Floridi 2004, 2007), describes information as 'data that is well ordered, meaningful and true'. ${ }^{8}$ Adding a datum with another datum we have data, but we do not necessarily have information. We need to have this data ordered in some way for it to be information. Consider the data set '_ beiklssyu'. Without order it is simply a jumble of data. In this case, letters and spaces. But if we order these data according to a set of rules or syntax, we can produce the data set 'sky_is_blue'.

One of the notable things about an ordered data set like 'sky is blue' is that it is meaningful, that is, it has semantic content. Gregory Bateson's slogan, that information "consists of differences that make a difference" (Bateson 1979) tracks

\footnotetext{
${ }^{8}$ As truth is a philosophically messy area, I am going to assume that Floridi's argument for the truth condition holds (Floridi 2005). A different way to cash out truth and information is described by Fred Dretske (Dretske 1981).
} 
to the meaningful condition of information. Note that this account of meaning tracks to the introductory section in this paper where meaning was described as capable of producing a change. In this case, the change can be related directly to knowledge. As such, a well ordered data set must have the potential to produce knowledge if it is to be counted as information (Dretske 1981).

Also, note that information is additive. Consider that we have a well ordered, meaningful true data set, and we add more data to it, or we add it to another data set. If order, meaning and truth are maintained, not only do we still have information, but we have more information, and I would also contend that we have new information. ${ }^{9}$ This means that adding new information to existing information produces new knowledge. Consider an example of solving a crime, where the results of an investigation are as follows: Officer Andy knows that the thief was male. Officer Belinda knows that the thief had to be less than $1.8 \mathrm{M}$ tall. Officer Chris knows that the thief had a key to the house. Officer Daisy knows that only one suspect from her list has no alibi for the time of the crime. In a process of epistemic group action (Miller 2007), adding these individual pieces of information together the investigative team have the new information that Edward Frish is the thief.

So, we have data, information and knowledge. Data produces information and information produces knowledge. Information is well ordered, meaningful and true data with the capacity for addition. As said, this is a general description of a concept of information but doesn't really tell us a great deal. However once we start describing different kinds of information, we can achieve some interesting differences. A final point to make about these three information kinds is that that a single piece of information may be classified by different people as any of the three different kinds.

\section{Source information}

This kind of information is information that can be considered as a complete set, capable of being broken down into smaller units. That is, sections of data can be taken from the source information and these sections can then reliably be described as information. A paradigmatic example would be a DNA sequence. It is composed of data. This data would likely be ordered and if a reader knows what the sequence is, it is meaningful.

When describing the Source Information as a complete set, this does not mean that the set is closed. Imagine I were standing in a park, playing with a puppy. In this example, there is an inordinate amount of information found at the source. Consider trying to create a list that has every piece of data, all the relations between the data, all possible meanings, etc, and then add the temporal dimension to this scene. The point here is that a given source may have an overwhelming amount of information contained within it. To paraphrase Alan Chalmers, 'what is needed in science is not just information, but relevant information' (Chalmers 1999). Indeed, this claim is true not just for scientific enquiry, but for communication also (Fish and Veeser

\footnotetext{
${ }^{9}$ The general principle driving this point is that information is emergent. That is, something new emerges from the addition recombination simpler units. A claim like this is controversial but can't be argued for here.
} 
1999). At the level of Source Information, to make information intelligible we need limits on what that information is.

Implicit in such claims that we narrow our Source Information in scientific enquiry or communication, is that value judgments are being made as to what limits are placed around an information set. If we are not simply recording every available piece of data about the world, then we are selecting between data that ought to be included and data that ought to be omitted. Langdon Winner has argued that artefacts have politics (Winner 1980), and Jeroen van den Hoven argues that values are incorporated into design (van den Hoven 2007), and this value-ladeness in part is based on what information is included in Source Information.

\section{Message information}

For Message information, consider it as a selection of Source Information. That is, a section of Source Information has been accessed, retrieved or communicated. Message Information may be something as simple as a signal. Consider a fuel gauge on a car-when the fuel drops below a given level, a light on the dashboard is activated. This signals to the driver that the fuel is below a given level. Note that the signal is a limited information set taken from a larger set. On my account, Message Information tracks to some form of communication between source and receiver. So Message Information is a limited set of Source Information as part of communication between a source and receiver.

While Source Information and Message Information can be applied in many ways, one way to conceive of the Message Information in relation to DNA is as a subsection of a full DNA sequence. An STR profile or the MAOA gene sequence can be understood as Message Information as they are subsections of a person's full DNA sequence. In selecting a particular subsection of DNA, one is making a judgment about which information is important. The point here is that Message Information is not ethically inert, or at very least it is value laden (Ossorio 2006; Stevens 2003). We ought to recognise this fact, as it undercuts claims that information generally, and Message Information in particular, is necessarily objective or amoral.

\section{Receiver information}

For Receiver Information consider it as Message Information, from a source that has been received by a receiver of some kind. In the case of the fuel gauge, the driver of the car receives a message - a dashboard light is now on and they understand it as meaning that the fuel has dropped below a certain level. This Message Information has nested within it a host of meanings, depending on what information the receiver already has. The driver knows that the particular icon lighting up on the dash is communicating the state of the fuel level. If the driver didn't know this, the message fails in communicating the meaning.

Given the knowledge that people already have, the same piece of Message Information can mean very different things to different people. Consider the earlier example of the four police officers, Andy, Belinda, Chris and Daisy identifying a thief. If officer Gina already knows that the thief was male, was less than $1.8 \mathrm{M}$ tall 
and had a key to the house and overhears Daisy say that Edward Frish was not home at the time of the theft, Gina may now know that Edward Frish is the thief, while Daisy does not.

[T] he single observation...carries the same information to both of [them]. The explanation for why [Gina] learned more from it than [Daisy]...is that [Gina] knew more to begin with...The latter piece of information is...nested in the former piece of information...This constitutes a relativization of the information contained in a signal because how much information a signal contains, and hence what information it carries, depends on what the potential receiver already knows about the various possibilities that exist at the source (Dretske 1981 Emphasis Mine).

The claim is that the beliefs and knowledge that the receiver has prior to receiving Message Information will influence the Receiver Information produced from the message.

Making clear that there is a distinction between Message Information and Receiver Information is important. The reason is that the two kinds of information go some way to explaining why confusion and conflict can arise between different people. Consider the MAOA Gene. The Message Information from the Alia-Klein et al. article is that there is "evidence linking the low MAOA genotype and violent behavior but only through interaction with severe environmental stressors during childhood" (Alia-Klein et al. 2008 Emphasis Mine). Note here the importance of the full message, that low-copy variants alone are not sufficient for violent behaviour. If one is to get the information that low-copy variants cause violent behaviour, and that Maoris have the low-copy variants, then one can believe that Maoris are genetically predisposed to violence. The Receiver Information is based on scientifically relevant Message Information, but as it is incomplete, the receiver can shift from the intended Character Identity concept to an Essentialised Identity concept.

Receiver Information brings us back to meaning. Message Information, when integrated with a cognitive agent's existing beliefs and knowledge can produce many different meanings. If a person's meaning of 'genetic identity' is built from an integration of the Nominal Gene with Numeric Identity, they will likely have a different meaning to someone whose meaning of 'genetic identity' arises from an integration of Instrumental Genes with Group Identity. The Receiver Information is going to provide different meanings for different people, due in part to the concepts they are using to form their thoughts.

Receiver Information explains two further points. Firstly, it explains why people of different disciplines will form different ideas when a phrase like 'genetic information is necessary for identity formation' is used: the concepts selected are partially influenced by the existing beliefs of the person receiving the Message Information. Secondly, as Receiver Information differs across different people, this may result in different responses to the same Message Information. Consider the different responses between a police officer thinking of STRs and a sociologist thinking of MAOA, when both hear the phrase 'genetic information is necessary for identity formation'. It may be that the police officer will see this as a good state of affairs, that it ought to be supported for the social good, while it may be that the sociologist sees this as a bad state of affairs, that ought to be opposed for the social 
good. The person's existing knowledge informs not only their values but the responses to those values. More importantly, the Receiver Information can have different meanings for different people, even when those people have the same value commitments. Both the police officer and the sociologist may desire the social good, but because of conceptual differences, they may strongly differ in their actions.

\section{The concept creeps: why we should care about conceptual misconnections}

So far what has been said in this paper may not be terribly surprising: different concepts exist for different words. A person may take a particular word to track to a particular concept, being unaware that a different discipline may have a different concept in mind. So what? The introductory parable of Frank and Carter was an example of people talking past each other, but is there more to be concerned about than simple confusion? I believe there is, and the reason can found by looking at concept creep. In this section I will introduce concept creep and then illustrate concept creep by reference to genetic information, identity and criminal justice.

\section{Concept creep and slippery slopes}

The idea of concept creep is similar to a slippery slope argument. Labelling something a 'slippery slope' argument is often meant as a defeater of the argument. There are, however, situations where a slippery slope argument is rightly used to describe something unwanted. Arising from conceptual misconnection, concept creep is similar to a valid slippery slope argument, and arises in situations of interdisciplinary communication, with, in Bernard William's terms, potentially 'horrible results' (Williams 1985).

Fred Schauer's approach to a valid slippery slope looks explicitly at legal theory, whereby a particular innocuous legal decision should not be taken as it can lead to unwanted legal decisions in the future. "A slippery slope argument claims that permitting the instant case - a case that it concedes to be facially innocuous and that it linguistically distinguishes from the danger case-will nevertheless lead to, or increase the likelihood of, the danger case" (Schauer 1985-1986). One of the reasons for this, argues Schauer, is 'linguistic imprecision' (Schauer 1985-1986). The particular relevance of Schauer's account is that the 'horrible result' arises due to the vagueness of language: "linguistic boundaries between the [innocuous] case and the [horrible] case will be weaker. As a consequence, the language will be less effective in distinguishing different cases, thus producing an increased likelihood of unintended and unwanted results" (Schauer 1985-1986).

I believe that there are strong overlaps between Schauer's linguistic imprecision and conceptual misconnections. The concern is that the conceptual misconnections can allow ethically problematic practices, producing the 'horrible result.' If different people and different disciplines are familiar with the concepts that others intend a word to track to, then we reduce the possibility of these horrible results occurring. Concept creep, then, is the situation where a word that was initially intended to mean 
concept A takes on concept B, where concept A is ethically inert, while concept B is ethically charged. The transition between contexts allows the ethically innocuous concept to creep into ethically problematic territory.

Let us look at the phrase 'genetic information used to determine criminal identity'. This can have (at least) two different meanings, depending on the concepts involved. One meaning tracks to an ethically permissible action, such as the use of STRs to determine if a person had committed a particular crime. Another meaning is assumed to track to ethically impermissible action, the use of MAOA to claim that a particular racial group is genetically inclined to be violent gang members who use weapons. We can cash these two meanings out to the morally innocuous and the horrible results discussed by both Williams and Schauer.

The similarities between slippery slopes and concept creep become relevant when we consider two points. Firstly, that one meaning of 'genetic information used to determine criminal identity' tracks to a morally permissible action. Secondly, that the exact same phrase can track to a morally impermissible action, but a person receiving this might be unaware of the different concepts involved. That is, the Message Information might seem the same, but given the differences in Source Information, speaker intention, and audience beliefs and knowledge, the Receiver Information can be entirely different.

Genes, identity, information and concept creep

Throughout this paper, I have contrasted two different conceptual expositions of the relationship between different conceptions of genes, identity and information. On one account, an STR profile is used to confirm/deny that a particular person has been at a crime scene. On the second account, the low-variant of a particular gene MAOA has been linked to violence and a particular race, the Maori. I have assumed that, given certain conditions, the first account is permissible while the second account is ethically problematic. I have just described slippery slopes and referring to the STRs/ MAOA accounts, and shown how concept creep is similar to a valid slippery slope argument. The implication is that as STR is good, but MAOA is bad, so it may follow that we ought not to allow STRs to be used, in case MAOA is used. Yet, this is not what I want to say: there are many important differences between the STR and MAOA accounts.

Instead, what I want to show is how concept creep, arising from conceptual misconnections, can result in allowing that which is morally impermissible. First consider the STR account. One of the foundational premises of the STRs selected for use in forensic databases was that the STRs be non-coding sections of DNA. Yet, as we have seen, while this may omit Nominal Genes from being included, it allows Instrumental and Postgenomic Molecular Genes to be STRs. Secondly, following the assumption that non-coding means 'not-a-gene', the claim made in support of STR profiles is that they are morally equivalent to fingerprints, and can do no more than a fingerprint to confirm or deny a person's identity. This is explicitly appealing to Numeric Identity. Finally, STRs operate under the assumption that the genetic information is simply a value-free fact about the world. Yet, as we have seen, Message Information always carries value judgements with it, by what it includes and omits. When forensic samples are used to predict the race or familial relations of 
the culprit, these value judgements become highly problematic (Haimes 2006; Ossorio 2006).

The idea of conceptual misconnections explains how moral problems arise by way of concept creep. An STR profile is 'merely a fingerprint', yet a sample from a crime scene can tell us more than a simple fingerprint, something like race can also be guessed at. Now, we begin to creep from Numeric Identity into Group Identity. We find a seemingly objective scientific justification for targeting particular racial groups or familial groups in the course of an investigation, our concepts creeping further from the originally intended meaning, from Numeric to Group and then into Essentialised Identity. By being unclear about the fundamental concepts operating in STR profiles, we slip from that which is permitted into that which is morally problematic. The Message Information shifts with the context and as result the Receiver Information changes, producing change in meanings of the genetic information.

Now, consider the MAOA example. In 2008 "the entire research was called into disrepute" (Wensley and King 2008), while in 2010 we have an article linking violence, gang membership and weapon use via the MAOA gene (Beaver et al. 2010). If the early research was 'disreputable' why would people still be researching and publishing? There are two parts to explaining this. Firstly, as D. Wensley and M. King stated, the original research failed to properly contextualise their report (Wensley and King 2008). Though the research itself may be sound, without a firm context, intended meanings become lost, conceptual misconnections occur, and we have concept creep from Character Identity into Group Identity and Essentialised Identity.

The second part of this explanation comes back to the relationship between information and meaning. The concern that arises from use of 'genetic information' is that people confuse Source Information-presumed to track to natural facts about the world, with Message Information then with Receiver Information. Yet, as argued, Message Information is a value-directed subset of Source Information and Receiver Information is new information arising from what Message Information is effectively received and integrated with the person's existing beliefs. Although a researcher may intend that their Message Information be understood within a particular context, what Wensley and King refer to as the 'internal' context of science (Wensley and King 2008), if the Message Information is poorly communicated, the audience can form a very different meaning to that intended by the researchers.

One of the compounding factors to this is when only part of the research is effectively communicated:

Given that socio-economic factors...are likely to have a significant influence on the noted behaviours, we argue that the researchers failed in their obligation to clearly place the influence of increased levels of [MAOA] in its wider sociopolitical context. For this reason when the researchers ventured to explain the impact of the MAOA gene on antisocial behaviours without reference to other contributing social, cultural or other environmental influences, they failed to provide "socially robust" knowledge (Wensley and King 2008).

The relation of this to concept creep is, twofold. Firstly, that individual's complex multifactoral Character Identity is reduced, Essentialised, to a single genetic cause, and then coupled with the concept of Group Identity, as race. Secondly, that the 
background assumptions of the researchers are lost in transition from Source Information to Message Information to Receiver Information.

Evelyn Fox Keller stated "Can words have force in and of themselves? Of course not. They acquire force only through their influence on human actors" (Keller 1995). The point of this paper was to explain part of the mechanism for this influence on human actors, and to argue that there are problems when conceptual misconnections result in words influencing actors in morally problematic ways. I did this by showing there are different concepts for gene, identity and information, all of which are useful, and using concept creep, explained why users of these words ought to make clear which concept they mean to use.

Acknowledgments The author would like to thank Dion Oxley for looking at early drafts and to the reviewers and editor who provided worthwhile and very helpful feedback.

Open Access This article is distributed under the terms of the Creative Commons Attribution Noncommercial License which permits any noncommercial use, distribution, and reproduction in any medium, provided the original author(s) and source are credited.

\section{References}

Alia-Klein N, Goldstein RZ, Kriplani A, Logan J, Tomasi D, Williams B, et al. Brain Monoamine Oxidase A activity predicts trait aggression. J Neurosci. 2008;28(19):5099-104. doi:10.1523/jneurosci.0925-08.2008.

Bateson G. Mind and nature: a necessary unity. New York: E. P. Dutton; 1979.

Beaver KM, DeLisi M, Vaughn MG, Barnes JC. Monoamine Oxidase A genotype is associated with gang membership and weapon use. Compr Psychiatry. 2010;51(2):130-4.

Brunner HG, Nelen M, Breakefield XO, Ropers HH, Oost BAV. Abnormal behavior associated with a point mutation in the structural gene for monoamine oxidase A. Science. 1993;262(5133):578-80.

Chakraborty R, Stivers DN, Su B, Zhong Y, Budowle B. The utility of short tandem repeat loci beyond human identification: Implications for development of new DNA typing systems. Electrophoresis. 1999;20(8):1682-96.

Chalmers AF. What is this thing called science? 3rd ed. St Lucia: University Of Queensland Press; 1999.

Conrad P, Markens S. Constructing the 'gay gene' in the news: optimism and skepticism in the us and British press. Health (London). 2001;5(3):373-400. doi:10.1177/136345930100500306.

DeGrazia D. Human identity and bioethics. Cambridge: Cambridge University Press; 2005.

Dretske FI. Knowledge and the flow of information. Oxford: Blackwell; 1981.

Falk R. What is a gene? Stud Hist Philos Sci. 1986;17(2):133-73.

Fish SE, Veeser HA. The Stanley Fish reader. Malden: Blackwell; 1999.

Floridi L. Information. In: Luciano F, editor. The Blackwell guide to the philosophy of computing and information. Oxford: Blackwell; 2004.

Floridi L. Is semantic information meaningful data? Philos Phenomenol Res. 2005;70(2):351-70.

Floridi L. Semantic conceptions of information. In: The Stanford Encyclopedia Of Philosophy. 2007. http://plato.stanford.edu/archives/spr2007/entries/information-semantic/. Accessed 24/08/07.

Fodor JA. The language of thought. Harvard: Harvard University Press; 1975.

Frankfurt HG. Freedom of the will and the concept of a person. J Philos. 1971;68(1):5-20.

Friedman M. Autonomy, social disruption and women. In: Mackenzie C, Stoljar N, editors. Relational autonomy: feminist perspectives on automony, agency, and the social self. New York: Oxford University Press; 2000. p. 35-51.

Greely HT, Riordan DP, Garrison NA, Mountain JL. Family ties: The use of DNA offender databases to catch offenders' kin. The Journal Of Law, Medicine \& Ethics. 2006;34(2):248-62. doi:10.1111/ j.1748-720X.2006.00031.x.

Grice HP. Meaning. Philos Rev. 1957;66(3):377-88. 
Griffiths PE, Stotz K. Genes in the postgenomic era. Theor Med Bioethics. 2006;27:499-521.

Haimes E. Social and ethical issues in the use of familial searching in forensic investigations: Insights from family and kinship studies. J Law Med Ethics. 2006;34(2):263-76. doi:10.1111/j.1748720X.2006.00032.x.

Hamer DH, Hu S, Magnuson VL, Hu N, Pattatucci AML. A linkage between DNA markers on the $\mathrm{x}$ chromosome and male sexual orientation. Science. 1993;261(5119):321-7.

Haslanger S. Gender and race: (what) are they? (what) do we want them to be? Noüs. 2000;34(1):31-55.

Haslanger S. What are we talking about? The semantics and politics of social kinds. Hypatia. 2005;20 (4): $10-26$.

Hauskeller C. Genes, genomes and identity. Projections on matter. New Genet Soc. 2004;23(3):28599.

Jobling MA. In the name of the father: surnames and genetics. Trends Genet. 2001;17(6):353-7.

Keller EF. Refiguiring life: metaphors of twentieth century biology. New York: Columbia University Press; 1995.

Levy N. Neuroethics: challenges for the 21st century. Cambridge: Cambridge University Press; 2007.

MacIntyre AC. After virtue: a study in moral theory. 3rd ed. Notre Dame: University Of Notre Dame Press; 2008.

Mackenzie C. Imagining oneself otherwise. In: Mackenzie C, Stoljar N, editors. Relational autonomy: feminist perspectives on autonomy, agency, and the social self. New York: Oxford University Press; 2000. p. $124-50$.

Mackenzie C. Relational autonomy, normative authority and perfectionism. J Soc Philos. 2008;39(4):51233.

Mackie D. Personal identity and dead people. Philos Stud. 1999;95(3):219-42.

Mann CC. Behavioral genetics in transition. Science. 1994;264(5166):1686-9.

Mennell J, Shaw I. The future of forensic and crime scene science: Part I. A UK forensic science user and provider perspective. Forensic Science International. 2006;157(Supplement 1):S7-S12.

Miller S. Collective moral responsibility and information and communication technology. In: van den Hoven J, Weckert J, editors. Information technology and moral philosophy. Cambridge: Cambridge University Press; 2007.

Moss L. What genes can't do. Massachusetts: MIT; 2004.

Olson ET. Personal identity. In: Zalta EN, editor. The Stanford encyclopedia of philosophy. Spring 2007 ed., 2007.

Ossorio PN. About face: forensic genetic testing for race and visible traits. J Law Med Ethics. 2006;34 (2):277-92. doi:10.1111/j.1748-720X.2006.00033.x.

Parfit D. Personal identity. Philos Rev. 1971;80(1):3-27.

Parfit D. Reasons and persons. Reprinted with corrections, 1987. ed. Oxford: Clarendon Press; 1987.

Perry J. A dialogue on personal identity and immortality. Indianapolis: Hackett; 1978.

Perry J, editor. Personal identity. 2nd ed. Berkeley: University Of California Press; 2008a.

Perry J. The problem of personal identity. In: Perry J, editor. Personal identity. 2nd ed. Berkeley: University Of California Press; 2008b. p. 3-30.

Putnam H. The meaning of "Meaning". In: Gunderson K, editor. Minnesota studies in the philosophy of science: Volume vii language, mind, and knowledge. Minneapolis: University Of Minnesota; 1975.

Schauer F. Slippery slopes. Harvard Law Review. 1985-1986;99:361-83.

Sellars W. The structure of knowledge. In: Castañeda H-N, editor. Knowledge and reality: studies in honor of Wilfrid Sellars. Indianapolis: Bobbs-Merrill; 1975.

Smedley A, Smedley B. Race as biology is fiction, racism as a social problem is real: anthropological and historical perspectives on the social construction of race. Am Psychol. 2005;60(1):16-26.

Stevens J. Racial meanings and scientific methods: changing policies for NIH-sponsored publications reporting human variation. J Health Polit Policy Law. 2003;28(6):1033-88. doi:10.1215/0361687828-6-1033.

Straub J. Personal and collective identity: a conceptual analysis. In: Friese H, Assmann A, editors. Identities: time, difference, and boundaries. New York: Berghahn Books; 2002. p. 56-76.

Taylor C. The sources of the self: the making of modern identity. New York: Cambridge University Press; 1989.

Taylor C. The politics of recognition. In: Gutman A, editor. Examining multiculturalism and the politics of recognition. 2nd ed. Princeton: Princeton University Press; 1994. p. xi. 112 p.

U.K. Government. The national DNA database. In: Technology POOSA, editor. London: U.K. Parliament; 2006.

U.S. Government. Combined DNA index system. DNA Initiative. 2010. http://www.dna.gov/dnadatabases/codis. Accessed 20 June, 20102010. 
van den Hoven J. ICT and value sensitive design. In: Goujon P, Lavelle S, Duquenoy P, Kimppa K, Laurent V, editors. The information society: innovation, legitimacy, ethics and democracy in honor of Professor Jacques Berleur s.J., vol International Federation for Information Processing. Boston: Springer; 2007. p. 67-72.

Watson JD, Crick FHC. Molecular structure of nucleic acids: a structure for deoxyribose nucleic acid. Nature. 1953;171(4356):737-8.

Wensley D, King M. Scientific responsibility for the dissemination and interpretation of genetic research: lessons from the "warrior gene" controversy. J Med Ethics. 2008;34(6):507-9. doi:10.1136/ jme.2006.019596.

Williams B. The self and the future. Philos Rev. 1970;79(2):161-80.

Williams B. Which slopes are slippery? In: Lockwood M, editor. Moral dilemmas in modern medicine. Oxford: Oxford University Press; 1985. p. 126-37.

Williams R, Johnson P. 'Wonderment and dread': representations of DNA in ethical disputes about forensic DNA databases. New Genet Soc. 2004;23(2):205-23.

Williams R, Johnson P. Inclusiveness, effectiveness and intrusiveness: issues in the developing uses of DNA profiling in support of criminal investigations. J Law Med Ethics. 2006;34:234-47.

Winner L. Do artefacts have politics? Daedalus. 1980;109:121-36.

Zins C. Conceptual approaches for defining data, information, and knowledge. J Am Soc Inf Sci Technol. 2007;58(4):479-93. 